PaUlina SZYja

Uniwersytet Pedagogiczny, Kraków, Polska

\title{
Rola rozwiązań przyjaznych dla środowiska naturalnego w procesach restrukturyzacji przemysłu
}

\section{The role of environmentally-friendly solutions in the process of industrial restructuring}

\begin{abstract}
Streszczenie: Dokonująca się obecnie trzecia rewolucja przemysłowa jest związana z dążeniem do zwiększenia wydajności w zakresie wykorzystywania surowców oraz energii w procesach produkcyjnych. Podobne działania przyczyniają się do zmniejszenia oddziaływania tego sektora na środowisko naturalne. Artykuł przedstawia zagadnienie wdrażania rozwiązań przyjaznych dla środowiska naturalnego w kontekście dostrzeżenia roli przemysłu dla ożywienia gospodarki po okresie kryzysu. Uwzględnia przy tym korzyści i ewentualne koszty tego rodzaju działań na płaszczyźnie makro, odnoszącej się do całego sektora przemysłu (czy szerzej - gospodarki), oraz mikro, tj. sytuacji zakładów.
\end{abstract}

\begin{abstract}
The third industrial revolution, that is happening at the moment, is associated with the desire to increase efficiency in the use of raw materials and energy in production processes. Similar activities contribute to reducing the impact that this sector has on the environment. The article presents the issue of deployment of environmentally friendly solutions in industry in the context of overcoming economic crisis. Taking into account the potential benefits and costs of such actions at the level of macro, referring to the entire industry (or in the wider economy), and micro, the conditions of production plants.
\end{abstract}

Słowa kluczowe: ekoinnowacje; przemysł; restrukturyzacja; wydajność; zielona gospodarka

Keywords: ecoinnovation; industry; restructuring; productivity; green economy

\section{WsTĘP}

Rozwój przemysłu pod koniec XVIII i na początku XIX w., zainicjowany dzięki wielu wynalazkom, a szczególnie maszynie parowej, przyczynił się do zmian nie tylko w sferze gospodarczej, ale i społecznej. Zapoczątkowane przekształcenia strukturalne pozwoliły na efektywne wykorzystywanie zasobów wytwórczych pozostających w dyspozycji poszczególnych gospodarek. Proces ten był następnie kontynuowany, a ogromną rolę w tym zakresie 
odegrało dążenie do zautomatyzowania działalności wytwórczej. W rezultacie lata 70. i 80. XX wieku to ogromny skok technologiczny, szczególnie w gospodarkach państw Europy Zachodniej, w Stanach Zjednoczonych, a także Japonii. Kolejny okres, szczególnie koniec lat 90. XX i początek XXI wieku, charakteryzuje się jednak spadkiem znaczenia tego sektora z uwagi na rozwój usług. Kryzys gospodarki realnej z okresu 2008-2010 sprawił, że ponownie zwrócono uwagę na znaczenie przemysłu dla całej gospodarki. W ramach działań związanych z przezwyciężeniem skutków kryzysu i wypracowywaniem nowych ram rozwojowych wskazano na potrzebę wprowadzenia jakościowo nowych przekształceń strukturalnych, związanych z wdrażaniem innowacji technologicznych w procesach produkcyjnych, które spełniają wysokie wymagania w zakresie wydajności i efektywności, a jednocześnie pozwalają na zmniejszenie uciążliwości dla środowiska naturalnego.

Przedmiotem niniejszego opracowania jest analiza działań na rzecz zazielenienia przemysłu, określanych mianem trzeciej rewolucji przemysłowej, w kontekście ewentualnych procesów restrukturyzacyjnych. W artykule prezentowane są podstawowe pojęcia związane z postępującymi zmianami. Uwzględniono także wielkości nakładów na projekty inwestycyjne w układzie przestrzennym. Ponadto prezentowane są koszty i korzyści wprowadzania ekologicznych rozwiązań w przemyśle, a także czynniki umożliwiające ich intensyfikowanie bądź przeciwnie, stanowiące bariery.

Autorka stawia następującą hipotezę: rola rozwiązań przyjaznych dla środowiska naturalnego w przemyśle stanowi element procesów restrukturyzacyjnych na drodze do zazieleniania tego sektora.

\section{ZMIANY W PROCESIE UPRZEMYSŁOWIENIA GOSPODAREK}

Załamanie na rynkach finansowych, którego pierwsze symptomy były diagnozowane już w 2007 roku, doprowadziło do globalnego kryzysu. Początkowo miał on wymiar jedynie finansowy, ale jego skutki szybko wpłynęły na realną sferę gospodarek poszczególnych państw, zwłaszcza tych, które miały rozwinięte rynki finansowe. Warto w tym miejscu przytoczyć opinię G.W. Kołodki, którego zdaniem: „Skala oderwania się sektora finansowego od realnej gospodarki, w której wytwarza się niezbędne do życia - i do procesu reprodukcji - dobra i świadczy usługi, była tak wielka, że niezbędne dostosowanie, które musi polegać na niwelacji rozmiarów tegoż oderwania, mogło dokonać się jedynie przez kryzysową korektę wstrząsową" (Kołodko, 2010: 93). W wyniku kłopotów instytucji finansowo-bankowych przedsiębiorstwa, szczególnie produkcyjne, zaczęły borykać się z wieloma trudnościami. Przykładem tego stanu rzeczy była groźba bankructwa potentatów motoryzacyjnych General Motors, Chrysler i Ford. Spadek sprzedaży dóbr pociągnął za sobą konieczność ograniczenia produkcji, czasowe przestoje, a także zwolnienia. W ujęciu globalnym nastąpił spadek PKB wielu państw i wzrosło bezrobocie w okresie 2008-2010 (tab. 1). Warto podkreślić, że Polska była jedynym krajem członkowskim Unii Europejskiej, w którym nie odnotowano ujemnej wartości pierwszego wskaźnika. 
Tab. 1. PKB i stopa bezrobocia wybranych państw w latach 2008-2010

\begin{tabular}{|l|r|r|r|r|r|c|}
\hline \multirow{2}{*}{ Wyszczególnienie } & \multicolumn{2}{|c|}{2008} & \multicolumn{2}{c|}{2009} & \multicolumn{2}{c|}{2010} \\
\cline { 2 - 7 } & PKB & $\begin{array}{c}\text { Stopa } \\
\text { bezrobocia }\end{array}$ & PKB & $\begin{array}{c}\text { Stopa } \\
\text { bezrobocia }\end{array}$ & PKB & $\begin{array}{c}\text { Stopa } \\
\text { bezrobocia }\end{array}$ \\
\hline Niemcy & 1,1 & 7,5 & $-5,1$ & 7,8 & 4,0 & 7,1 \\
\hline Estonia & 7,3 & 13,5 & $-14,1$ & 16,7 & 3,3 & 12,3 \\
\hline Irlandia & $-2,2$ & 6,4 & $-6,4$ & 12,0 & $-1,1$ & 13,9 \\
\hline Francja & 2,3 & 7,5 & $-0,1$ & 9,1 & $-3,1$ & 9,3 \\
\hline Polska & 5,1 & 7,1 & 1,6 & 8,1 & 3,9 & 9,7 \\
\hline Wielka Brytania & $-0,8$ & 5,6 & $-5,2$ & 7,6 & 1,7 & 7,8 \\
\hline Stany Zjednoczone & -1, & 5,8 & $-5,5$ & 9,3 & 4,7 & 9,6 \\
\hline
\end{tabular}

Źródło: Eurostat

Konieczne stało się podjęcie działań ukierunkowanych na przezwyciężenie kryzysu. Głównymi podmiotami zaangażowanymi były państwa, mimo iż, zgodnie z rozpowszechnioną doktryną liberalizmu w duchu założeń Miltona Friedmana, nie powinny one ingerować w wolny rynek. Przejawem ich aktywności było przyjęcie programów antykryzysowych (Szyja, 2011: 66-80). W Stanach Zjednoczonych uchwalono American Recovery and Reinvestment Plan, którego wartość wyniosła 787 mld dolarów. Z kolei dla Unii Europejskiej przygotowano European Economic Recovery Plan. W obu dokumentach wskazano na konieczność podjęcia działań, które nie tylko przyczynią się do ożywienia gospodarczego, lecz pozwolą na stworzenie ram rozwojowych w długim okresie. Dlatego też podkreślono rolę inwestycji związanych ze zmianami strukturalnymi, które pozwolą w przyszłości ograniczyć wrażliwość na podobne kryzysy, zmniejszą uciążliwość oddziaływania procesów gospodarczych na środowisko naturalne i jednocześnie umożliwią sprostanie wyzwaniom, takim jak postępujące zmiany klimatyczne. Cechą wyróżniającą tych programów było przeznaczenie środków na projekty infrastrukturalne oraz inwestycje przyjazne dla środowiska naturalnego. Według raportu HSBC udział zielonych instrumentów stymulacyjnych w programach antykryzysowych wyniósł odpowiednio: w Unii Europejskiej - 58,8\%, w Stanach Zjednoczonych - 12\%, w Chinach - 37,8\% (Robins, 2008: 2).

Uwzględnienie tych środków i ich celowy dobór był podyktowany propozycjami m.in. Programu Narodów Zjednoczonych ds. Środowiska (UNEP), związanymi ze stworzeniem Zielonego Nowego Ładu (Green New Deal). Jego głównym elementem jest zielona gospodarka, definiowana jako gospodarka, w której wzrost dochodów i zatrudnienia jest powodowany publicznymi i prywatnymi inwestycjami związanymi z redukcją emisji gazów i zanieczyszczeń, zwiększeniem efektywności wykorzystania energii i surowców, ochroną bioróżnorodności i ekosystemu. Tworzenie zielonej gospodarki wymaga zmian strukturalnych, związanych z osiągnięciem następujących celów:

- zwiększenie wydajności procesów produkcyjnych,

- ograniczenie energochłonności,

- ograniczenie materiałochłonności, 
- poszukiwanie i wdrażanie innowacji,

- poszukiwanie nowych przewag konkurencyjnych.

Działania w tym zakresie rozpoczęto w wielu krajach w latach 2008-2009 (Szyja, 2013a: 183-196), poczyniono wtedy pierwsze inwestycje ukierunkowane na „zazielenienie” poszczególnych sektorów. Tego rodzaju aktywność w obszarze przemysłu można określić mianem „trzeciej rewolucji przemysłowej” (choć pojawia się również określenie „nowa rewolucja przemysłowa), rozumianej jako praktyczna implementacja zasad zrównoważonego i trwałego rozwoju (Jovane i in., 2008: 641).

Warto przypomnieć, jakie zmiany towarzyszyły wcześniejszym rewolucjom przemysłowym i jakie elementy uzasadniają przyjęcie takiej nazwy obecnie. Pierwsza rewolucja rozpoczęła się pod koniec XVIII w. i była związana z maszyną parową. Wynalazek Jamesa Watta umożliwił zwiększenie wydajności i przeniesienie produkcji z domów do fabryk, rozwój kolei żelaznej, transportu rzecznego (statki parowe na rzece Missisipi w Stanach Zjednoczonych) (Szpak, 2007: 184-186). Rewolucja przemysłowa zapoczątkowana w Wielkiej Brytanii przyczyniła się do wzrostu podziału pracy, zwiększenia ilości oferowanych dóbr, a także zmian w strukturze produkcji w wielu krajach. Dokonujące się wówczas przekształcenia spowodowały podział na państwa bogatej Północy i biednego Południa. Pierwsze charakteryzowały się rozwojem różnych dziedzin przemysłu, których rezultaty w postaci dóbr eksportowały do drugiej grupy państw. Te z kolei swoją politykę gospodarczą koncentrowały na rozwoju rolnictwa, ze względu na ograniczone możliwości inwestycyjne związane $\mathrm{z}$ industrializacją. W tym ostatnim przypadku należy odwołać się do rozważań Ragnara Nurksa w zakresie przezwyciężenia ,zaklętego kręgu ubóstwa”, czyli sytuacji, w której kraj zacofany nie jest w stanie wejść na drogę rozwoju (Fiedor, Kociszewski, 2010: 131-134).

Druga rewolucja przemysłowa była związana z postępem technicznym w drugiej połowie XX w. Głównie dzięki robotyzacji i komputeryzacji skrócono czas produkcji w przemyśle, zmniejszono zatrudnienie i rozszerzono asortyment. Nastąpił też wzrost obrotów w handlu międzynarodowym.

Wyróżnikiem trzeciej rewolucji przemysłowej jest zwiększanie wydajności procesów wytwórczych i oddziaływanie na zmniejszenie ich uciążliwości dla środowiska naturalnego. Stąd tak duży nacisk kładzie się obecnie na wprowadzanie oszczędności w produkcji poprzez zwiększenie efektywności w zakresie wykorzystywanych surowców, a także energii elektrycznej. Sposobami na osiągnięcie tego celu mają być takie działania, jak:

- wprowadzanie technologii oszczędzających zasoby i energię,

- przekształcanie budynków fabryk w mikroelektrownie,

- magazynowanie energii,

- zmniejszenie ilości odpadów towarzyszących procesom produkcyjnym,

- rozszerzenie asortymentu o produkty ekologiczne.

Działania ukierunkowano głównie na sektor przemysłowy, zarówno w Stanach Zjednoczonych, jak i krajach członkowskich Unii Europejskiej, z uwagi na kilka kluczowych kwestii. Pierwsza dotyczy oddziaływania produkcji przemysłowej na środowisko naturalne m.in. poprzez emisję gazów cieplarnianych (tab. 2). 
Tab. 2. Emisja gazów cieplarniach przez poszczególne sektory w Unii Europejskiej (28 państw) w latach 2000-2012 (1000 ton ekwiwalentu $\mathrm{CO}_{2}$ )

\begin{tabular}{|l|r|r|r|r|c|}
\hline \multicolumn{1}{|c|}{ Wyszczególnienie } & \multicolumn{1}{c|}{2000} & \multicolumn{1}{c|}{2008} & \multicolumn{1}{c|}{2010} & \multicolumn{1}{c|}{2012} & $2012 / 2000$ \\
\hline całkowita emisja $\mathrm{CO}_{2}$ & 5237920 & 5149786 & 4883456 & 4678812 & 0,89 \\
\hline przemysł energetyczny & 1508243 & 1538015 & 1435590 & 1408894 & 0,93 \\
\hline $\begin{array}{l}\text { przemysł wytwórczy } \\
\text { i budownictwo }\end{array}$ & 706655 & 633207 & 567534 & 533060 & 0,75 \\
\hline transport & 917992 & 966801 & 936275 & 893060 & 0,97 \\
\hline procesy przemysłowe & 393925 & 388215 & 334750 & 320632 & 0,81 \\
\hline rolnictwo & 521026 & 489477 & 474938 & 469104 & 0,90 \\
\hline odpady & 189569 & 156334 & 147323 & 140803 & 0,74 \\
\hline
\end{tabular}

Źródło: Eurostat

Jak wskazują dane, udział przemysłu w emisji gazów cieplarnianych jest przeważający w porównaniu z innymi sektorami. W analizach Eurostatu wyróżnia się przy tym trzy obszary przemysłu: energetyczny, wytwórczy oraz procesy przemysłowe.

Kolejna kwestia dotyczy roli przemysłu dla kształtowania produktu krajowego brutto. W wielu krajach udział sektora usług przekracza 70\%. Natomiast przemysł, po długim, bo obejmującym ponad dwa wieki okresie dominacji, stracił na znaczeniu i jego wkład nie stanowi więcej niż 30\% (tab. 3.)

Tab. 3. Wartość dodana brutto sektorów przemysłu i usług w wybranych państwach (\% PKB)

\begin{tabular}{|l|c|c|c|c|}
\hline \multirow{2}{*}{ Wyszczególnienie } & \multicolumn{2}{|c|}{ Przemysł } & \multicolumn{2}{c|}{ Usługi } \\
\cline { 2 - 5 } & 2010 & 2013 & 2010 & 2013 \\
\hline Austria & 29 & 29 & 70 & 70 \\
\hline Belgia & 23 & 21 & 77 & 78 \\
\hline Brazylia & 28 & 25 & 67 & 69 \\
\hline Chiny & 41 & 44 & 43 & 46 \\
\hline Czechy & 37 & 38 & 61 & 60 \\
\hline Dania & 22 & 21 & 77 & 77 \\
\hline Finlandia & 28 & 26 & 69 & 72 \\
\hline Francja & 19 & 19 & 79 & 79 \\
\hline Niemcy & 30 & 30 & 69 & 69 \\
\hline Polska & 32 & b.d. & 65 & b.d. \\
\hline Grecja & 17 & 16 & 80 & 80 \\
\hline Indie & 27 & 25 & 55 & 57 \\
\hline Włochy & 25 & 24 & 73 & 74 \\
\hline Luksemburg & 13 & 12 & 87 & 88 \\
\hline Norwegia & 39 & 41 & 59 & 58 \\
\hline Rosja & 35 & 36 & 61 & 60 \\
\hline Wielka Brytania & 22 & 20 & 78 & 79 \\
\hline Stany Zjednoczone & 20 & b.d. & 79 & b.d. \\
\hline
\end{tabular}

Źródło: World Bank, http://data.worldbank.org/indicator/NV.SRV.TETC.ZS, http://data.worldbank.org/indicator/ NV.IND.TOTL.ZS 
Rozważania dotyczące przyczyn tego stanu rzeczy mają uzasadnienie zarówno w odniesieniu do usankcjonowanych w praktyce podstawowych założeń doktrynalnych, jak i do sytuacji w warunkach gospodarki wolnorynkowej. W pierwszym przypadku E. Mączyńska podkreśla, że spadek znaczenia przemysłu jest wynikiem zwycięstwa „doktryny neoliberalizmu i teorii monetarnej, którym podporządkowano realne procesy gospodarcze" (Stefaniak, 2014). Z kolei w drugim przypadku podkreśla się rolę czynników związanych z funkcjonowaniem firm w warunkach wolnorynkowych. Istotną rolę odgrywa tu niepewność w gospodarce, która przyczynia się do wyprowadzania wielu działalności i funkcji na zewnątrz przedsiębiorstw oraz zlecania ich podwykonawcom. Zwraca się także uwagę na wzrost heterogeniczności działalności podmiotów gospodarczych, a także zmiany w zakresie ich powiązań i koncentracji (Szmytkowska, Czepczyński, 2004: 43-44). Te ostatnie są z kolei efektem rewolucji informatycznej i postępu technologicznego, które umożliwiły przemieszczanie procesów produkcyjnych i modyfikacje w systemie zarządzania.

Ponadto należy wskazać na rolę przemysłu w kwestii zatrudnienia. W Polsce w 2012 roku w omawianym sektorze pracowało $30 \%$ wszystkich zatrudnionych w kraju, w Czechach $-38 \%$, podobnie na Słowacji, natomiast w Niemczech - 28\%, we Francji - 22\%, a w Wielkiej Brytanii - 19\% (World Bank). Podkreśla się, że działalność przemysłowa w większości regionów krajów wysoko rozwiniętych traci swoją funkcję aktywizacji zasobów pracy, co jest wynikiem postępującej mechanizacji i automatyzacji (Rachwał, Wiedermann, Kilar, 2009: 31). Ostatni kryzys pokazał jednak, że produkcja dóbr i kapitał powiązany stanowią podstawę kształtowania dobrobytu każdej gospodarki. Tym bardziej, że sektor ten w największym stopniu wykorzystuje osiągnięcia nauki i techniki oraz zapewnia możliwości rozwojowe innych sektorów poprzez bezpośrednie i pośrednie powiązania.

Nie mniej istotne jest podkreślenie, że przemysł wykazuje porównywalne zaangażowanie w zakresie wprowadzania ekoinnowacji produktowych oraz kształtowania orientacji ekologicznej przedsięwzięć. Na podstawie badań w Hiszpanii, podczas których poddano analizie 6000 przedsiębiorstw, w sektorze usług stwierdzono przewagę tego drugiego czynnika (Signes i in., 2014).

Biorąc pod uwagę wymienione czynniki, a także działania inwestycyjne państw w zakresie ożywienia gospodarek, należy wyraźnie podkreślić, iż obecnie mamy do czynienia ze zmianami w sektorze przemysłu. Są one podyktowane w pierwszej kolejności możliwościami, jakie generuje wzrost wydajności w procesach produkcyjnych w wyniku zastosowania rozwiązań przyjaznych dla środowiska naturalnego (Edwards, 2010).

\section{ROZWIĄZANIA PRZYJAZNE DLA ŚRODOWISKA NATURALNEGO W PRZEMYŚLE W Polsce A PROCESy ReSTRUKTURYZACJI}

Implementacja ekologicznych rozwiązań w przemyśle wymaga przeprowadzenia zmian jakościowych w sektorze, do czego z kolei potrzebna jest nowa polityka gospodarcza. Możemy mówić o polityce gospodarczej w szerokim i wąskim ujęciu. W pierwszym 
przypadku mamy do czynienia z takimi oddziaływaniami państwa, jak polityka podatkowa, celna, kredytowa czy zatrudnienia. W drugim przypadku państwo angażuje się w zmiany strukturalne sektora za pomocą instrumentów preferujących wybrane działy przemysłu (Kożuch, 2012: 73-74). Możemy wtedy mówić o przesunięciu zainteresowania z tradycyjnych działów do tzw. zielonych, identyfikowanych głównie z odnawialnymi źródłami energii, lub o skali mikro, związanej z przeprowadzaniem przekształceń z uwagi na konieczność dostosowania do zmian w otoczeniu zewnętrznym. Rodzaj, forma i zakres tych zmian zależą od wielu czynników, takich jak:

- sytuacja finansowa danego podmiotu,

- wielkość jednostek organizacyjnych,

- udział w rynku,

- wielkość i różnorodność oferowanych dóbr,

- przebieg procesu produkcyjnego,

- wydajność procesu produkcyjnego,

- innowacyjność,

- konkurencyjność,

- stopień wykorzystania osiągnięć nauki i techniki.

W jednym i drugim przypadku można mówić o procesach restrukturyzacji. Przy czym w odniesieniu do gospodarki są one związane z nadaniem nowego kierunku kształtowania ram rozwoju społeczno-gospodarczego. Z kolei w przedsiębiorstwie mają one służyć powiększeniu jego wartości rynkowej. Podkreśla się, że warunkiem powodzenia procesów restrukturyzacji jest radykalizm przeprowadzanych zmian (Rachwał, 2006: 99). Dokonujące się obecnie przekształcenia, ukierunkowane na tworzenie zielonej gospodarki i stanowiące element szerszego programu przekształceń jakościowych, charakteryzują się takimi właściwościami. Świadczą o tym m.in. cele postawione w ramach pakietu klimatyczno-energetycznego, przedstawionego przez Komisję Europejską w styczniu 2007 roku:

- zmniejszenie emisji gazów cieplarnianych przynajmniej o 20\% w 2020 roku w porównaniu do bazowego $1990 \mathrm{roku}$,

- zwiększenie udziału energii ze źródeł odnawialnych w zużyciu energii końcowej do $20 \%$ w 2020 roku,

- zwiększenie efektywności wykorzystania energii o 20\% do 2020 roku.

Sprostanie tym zadaniom wymaga od Polski, która jest uzależniona od energetyki węglowej, zdecydowanych działań (tab. 4.), głównie inwestycyjnych, ale również związanych z implementacją określonych regulacji prawnych, instrumentów finansowych i ekonomicznych.

Wdrażanie zmian związanych z rozwiązaniami przyjaznymi dla środowiska naturalnego wymaga inwestowania. W latach 2002-2011 nakłady inwestycyjne, rozumiane jako „nakłady finansowe lub rzeczowe, których celem jest stworzenie nowych środków trwałych lub ulepszenie (przebudowa, rozbudowa, rekonstrukcja lub modernizacja) istniejących obiektów majątku trwałego, a także nakłady na tzw. pierwsze wyposażenie inwestycji”" (Ochrona środowiska 2013, 2013: 389) ogółem w Polsce wzrastały. Największe zmiany związane z ich wzrostem widoczne są w latach 2010 i 2011, mimo iż jest to okres spowolnienia gospodarczego, na skutek kryzysu w Stanach Zjednoczonych i Europie Zachodniej. 
W sektorze przemysłowym nakłady na inwestycje charakteryzuje również wzrost w kolejnych latach. Należy jednak zwrócić uwagę na gwałtowny spadek poziomu nakładów w latach 2009-2010, a więc w okresie głębokiego kryzysu (tab. 5).

Tab. 4. Cele strategii Europa 2020 dla UE i dla Polski oraz postęp ich realizacji

\begin{tabular}{|l|c|c|c|}
\hline & Udział OZE & $\begin{array}{c}\text { Ograniczenie emisji } \\
\text { gazów cieplarnianych }\end{array}$ & $\begin{array}{c}\text { Efektywność } \\
\text { energetyczna }\end{array}$ \\
\hline $\begin{array}{l}\text { Europa 2020 } \\
\text { dla Polski }\end{array}$ & $15,48 \%$ & $-14 \%$ & 14 mln ton \\
\hline
\end{tabular}

Źródło: Cele w ramach strategii Europa 2020, http://ec.europa.eu/europa2020/pdf/target_pl.pdf

Tab. 5. Nakłady inwestycyjne ogółem w gospodarce narodowej i w przemyśle w latach 2008-2012 w tys. zł (ceny bieżące)

\begin{tabular}{|l|c|c|c|c|c|c|}
\hline & 2008 & 2009 & 2010 & 2011 & 2012 & $2012 / 2008$ \\
\hline $\begin{array}{l}\text { nakłady } \\
\text { inwestycyjne } \\
\text { ogółem } \\
\text { (w tys. zł) }\end{array}$ & 217259714 & 218580914 & 217287283 & 243346193 & 237627288 & 1,09 \\
\hline przemysł & 75316596 & 72073132 & 68979194 & 76778804 & 77521265 & 1,03 \\
\hline
\end{tabular}

Źródło: opracowanie na podstawie: Nakłady na środki trwałe..., 2013: 22

W latach 2009-2011 największe nakłady inwestycyjne w przemyśle miały miejsce w województwach: śląskim, mazowieckim i dolnośląskim. Natomiast najmniejsza wartość inwestycji przypada na województwa: podlaskie, opolskie i warmińsko-mazurskie. Z kolei w województwach kujawsko-pomorskim, łódzkim, pomorskim, świętokrzyskim i warmińsko-mazurskim odnotowano, w odróżnieniu od pozostałych regionów, spadek inwestycji w 2011 roku w porównaniu do 2009 roku (tab. 6.).

W zakresie inwestycji ekologicznych podejmuje się szczególnie działania na rzecz wdrażania green investment, ekoinnowacji oraz tworzenia green jobs. Pierwsze określenie odnosi się do zielonych inwestycji, czyli takich, które najczęściej są identyfikowane z odnawialnymi źródłami energii. Jednakże ich zakres jest szerszy, bowiem obejmuje technologie energooszczędne i zasobooszczędne, a także charakteryzujące się mniejszym poziomem emisji gazów cieplarnianych. Z kolei ekoinnowacje obejmują rozwiązania o charakterze substytucyjnym względem tradycyjnie stosowanych z uwagi na ich ograniczony zakres oddziaływania na środowisko naturalne.

Należy podkreślić, że ujęcie to nie jest kompletne. Trzeba uwzględnić także nowe technologie, nawiązujące do powszechnie nam znanych lub naśladujące je, a związane z nowymi rozwiązaniami w procesie produkcyjnym bądź częściej - z wprowadzaniem produktów i usług dotąd nieoferowanych na rynkach. 
Tab. 6. Nakłady inwestycyjne w przemyśle w poszczególnych województwach w latach 2009 i 2011 w tys. zł (ceny bieżące)

\begin{tabular}{|l|c|c|}
\hline \multicolumn{1}{|c|}{ Województwo } & 2009 & 2011 \\
\hline śląskie & 12360,2 & 13499,5 \\
\hline mazowieckie & 9253,1 & 9507,3 \\
\hline dolnośląskie & 7188,7 & 8111,7 \\
\hline wielkopolskie & 5438,1 & 7694,4 \\
\hline kujawsko-pomorskie & 5021,1 & 3370,5 \\
\hline łódzkie & 6225,7 & 5730,6 \\
\hline małopolskie & 3797,4 & 5129,9 \\
\hline podkarpackie & 2695,9 & 3652,3 \\
\hline pomorskie & 6113,3 & 3302,3 \\
\hline lubelskie & 1742,4 & 3050,4 \\
\hline zachodniopomorskie & 2293,2 & 2611,8 \\
\hline świętokrzyskie & 2675,5 & 2520,6 \\
\hline lubuskie & 1742,4 & 2415,9 \\
\hline podlaskie & 1071,7 & 2172,9 \\
\hline opolskie & 2000,1 & 2168,4 \\
\hline warmińsko-mazurskie & 1888,9 & 1840,3 \\
\hline
\end{tabular}

Źródło: Rocznik statystyczny przemystu, 2012: 330

Z kolei green jobs to zielone miejsca pracy. Próby definicji tego rodzaju miejsc pracy podjęli się eksperci różnych organizacji, m.in. Międzynarodowej Organizacji Pracy, Organizacji Współpracy Gospodarczej i Rozwoju, a także amerykańskiego Biura ds. Statystyki Zatrudnienia. Elementy wspólne prób zdefiniowania to powiązanie tego rodzaju miejsc pracy z inwestycjami w odnawialne źródła energii, redukcją emisji gazów cieplarnianych, energooszczędnością w budynkach, zakładach produkcyjnych, transporcie, a ponadto w gospodarce odpadami czy rolnictwie, leśnictwie i ochronie środowiska naturalnego. Green jobs mogą być tworzone w sektorach związanych z produkcją technologii przyjaznych dla środowiska naturalnego (Szyja, 2013b: 198-200).

Wdrażanie rozwiązań przyjaznych dla środowiska naturalnego odnosi się także do produktów, którym należy nadać takie właściwości, jak: energooszczędność, niski poziom emisji $\mathrm{CO}_{2}$, możliwość ich ponownego wykorzystania bez istotnych modyfikacji, recykling umożliwiający uzyskanie komponentów wykorzystywanych w innych dziedzinach produkcyjnych. W zastosowaniu podobnych rozwiązań pomaga zasada $3 \mathrm{R}$, czyli reduce, reuse, recycle. Polega ona na wprowadzeniu takich dóbr, które po okresie użytkowania mogą zostać poddane niewielkim modyfikacjom i ponownie zastosowane, a następnie poddane recyklingowi. Zarówno w fazie pierwszego wykorzystania, jak i kolejnego oraz recyklingu, ich stopień oddziaływania na środowisko naturalne jest wyraźnie mniejszy, aniżeli tradycyjnych produktów. 
Ekologiczne rozwiązania mogą być stosowane także w różnych obszarach funkcjonalnych przemysłu, np. w transporcie, logistyce, magazynowaniu poprzez zastosowanie samochodów ciężarowych, wózków widłowych, których napęd wykorzystuje zasilanie elektryczne bądź hybrydowe. Ponadto, szczególnie w Niemczech w sektorze motoryzacyjnym, prowadzona jest polityka związana z przekształcaniem budynków fabryk i zakładów produkcyjnych w mikroelektrownie dzięki zastosowaniu kolektorów słonecznych oraz technologii związanych z oszczędnością energii i wody.

W polskiej statystyce nie wyróżnia się poszczególnych z wymienionych kategorii, analizuje się natomiast wielkości nakładów na środki trwałe służące ochronie środowiska w przemyśle (tab. 7).

Tab. 7. Nakłady na środki trwałe służące ochronie środowiska w przemyśle w tys. zł. (ceny bieżące)

\begin{tabular}{|l|c|c|c|c|}
\hline & 2009 & 2010 & 2011 & $2011 / 2009$ \\
\hline $\begin{array}{l}\text { Nakłady na środki trwałe } \\
\text { służące ochronie środowiska } \\
\text { w przemyśle ogółem } \\
\text { w cenach bieżących } \\
\text { w tys. zł }\end{array}$ & 5859711,3 & 5586403,7 & 5897130,8 & 1,01 \\
\hline $\begin{array}{l}\text { ochrona powietrza } \\
\text { atmosferycznego i klimatu }\end{array}$ & 2013576,4 & 2063114,4 & 2970247,2 & 0,00001 \\
\hline gospodarka ściekowa & 2907234,2 & 2689118,7 & 2039537,7 & 0,70 \\
\hline $\begin{array}{l}\text { gospodarka odpadami, } \\
\text { ochrona gleb i wód }\end{array}$ & 794650,1 & 751109,3 & 772567,5 & 0,97 \\
\hline $\begin{array}{l}\text { zmniejszenie hałasu } \\
\text { i wibracji }\end{array}$ & 13685,6 & 27764,5 & 22121,1 & 1,62 \\
\hline
\end{tabular}

Źródło: Rocznik statystyczny przemystu, 2012: 476

Niewielka, choć utrzymująca się na stabilnym poziomie, wielkość nakładów na środki trwałe służące ochronie środowiska naturalnego w przemyśle może wynikać z kilku barier (Kassenberg, Śniegocki, 2010: 11-13):

- niedocenianie potencjału innowacyjnego technologii ekologicznych związanych ze zwiększaniem produktywności,

- niewystarczające finansowanie,

- brak wykwalifikowanych kadr,

- brak współdziałania przedsiębiorstw i jednostek badawczych,

- wysokie ryzyko inwestycji,

- obrona przemysłów schodzących oraz schyłkowych,

- nastawienie na dostępność i szybkość środków unijnych, a nie ich efektywne wykorzystanie.

Powyższe rozważania należy odnieść do danych statystycznych dotyczących rodzajów inwestycji przyjaznych dla środowiska w przemyśle. Wyróżnia się tzw. inwestycje końca rury, tj. urządzenia służące ochronie środowiska, niewpływające na proces produkcyjny 
(produkcja może być prowadzona bez nich), lecz redukujące lub eliminujące zanieczyszczenia już po ich wytworzeniu, oraz inwestycje w technologie zintegrowane, czyli stanowiące część większego procesu produkcyjnego, redukujące ilość i zmieniające jakość produkowanych zanieczyszczeń na bardziej przyjazne środowisku (tab. 8.) (Pojęcie stosowane w badaniach..., 2014). W sektorze gospodarczym dominują zdecydowanie te ostatnie, choć w przypadku górnictwa i wydobycia oraz przetwórstwa przemysłowego wiodącą rolę odgrywają inwestycje końca rury. Jest to rezultat specyfiki branży i jej oddziaływania na środowisko naturalne. W ujęciu całościowym także dominują inwestycje końca rury.

Tab. 8. Nakłady na środki trwałe służące ochronie środowiska w sektorze gospodarczym - inwestycje końca rury, inwestycje zintegrowane, w 2011 roku w tys. zł (ceny bieżące)

\begin{tabular}{|l|c|c|}
\hline \multicolumn{1}{|c|}{ Wyszczególnienie } & \multicolumn{2}{|c|}{2011} \\
\hline Rodzaj inwestycji & Inwestycje końca rury & $\begin{array}{l}\text { Inwestycje w zintegrowane } \\
\text { technologie }\end{array}$ \\
\hline Sektor gospodarczy & 1547584,9 & 1988656,4 \\
\hline $\begin{array}{l}\text { górnictwo } \\
\text { i wydobywanie }\end{array}$ & 62956,8 & 23208,2 \\
\hline $\begin{array}{l}\text { przetwórstwo } \\
\text { przemysłowe }\end{array}$ & 638576,7 & 147840,4 \\
\hline $\begin{array}{l}\text { wytwarzanie } \\
\text { i zaopatrywanie } \\
\text { w energię elektryczną, } \\
\text { gaz, parę wodną i gorącą } \\
\text { wodę }\end{array}$ & 846051,4 & \\
\hline $\begin{array}{l}\text { Sektor usług ochrony } \\
\text { srodowiska } \\
\text { dostawa wody; } \\
\text { gospodarowanie ściekami } \\
\text { i odpadami; rekultywacja }\end{array}$ & 2234058,5 & 12691,2 \\
\hline Suma & 3781643,4 & 2001347,6 \\
\hline
\end{tabular}

Źródło: Rocznik statystyczny przemystu, 2012: 480

Warto w tym miejscu podkreślić również rolę sektora usług ochrony środowiska, który jest analizowany w ramach sektora przemysłu. Udział nakładów tej gałęzi względem wielkości nakładów sektora gospodarczego stanowi ok. 38\% (2011).

Analizując powyższą kwestię, należy odnieść się do wyników badań w zakresie proekologicznych zachowań przedsiębiorstw. Przykład stanowi raport (obejmujący trzyletni okres) przygotowany przez Małopolskie Obserwatorium Gospodarki. Ekoinnowacje, które były i są podejmowane przez przemysł, obejmują w województwie (Proekologiczne zachowania..., 2011:36):

- technologie (37\%),

- zmiany organizacyjne (35,2\%),

- ekoinnowacje instytucjonalne (9,3\%). 
Jednocześnie trzeba zwrócić uwagę na przyczyny wprowadzania ekoinnowacji (Proekologiczne zachowania..., 2011: 18):

- chęć obniżenia kosztów (59\%),

- poprawa wizerunku firmy (47\%),

- poprawa stanu środowiska w okolicy (36\%),

- możliwość poprawienia sytuacji rynkowej (22\%),

- konieczność modernizacji technologii (21\%),

- przymus prawny $(16 \%)$,

- wzgląd na pracowników (12\%),

- nacisk lub wymogi stawiane przez klientów lub kontrahentów (5\%).

Mimo że powyższe dane dotyczą przedsiębiorstw bez rozróżnienia na sektory, można wysnuć wnioski, że przyczyny wdrażania ekoinnowacji przez przemysł są zbliżone.

Analizując działania związane z inwestycjami przyjaznymi dla środowiska naturalnego, należy zwrócić uwagę na koszty i korzyści tego rodzaju przedsięwzięć zarówno w skali mikro, jak i makro (tab. 9).

Tab. 9. Porównanie kosztów i korzyści ekoinnowacji w skali mikro i makro

\begin{tabular}{|l|l|l|}
\hline & \multicolumn{1}{|c|}{ Koszty } & \multicolumn{1}{|c|}{ Korzyści } \\
\hline Skala mikro & $\begin{array}{l}\text { - czasowe ograniczenie produkcji } \\
\text { - szkolenie pracowników } \\
\text { - koszty pozyskania nowych klientów } \\
\text { i wejście na nowe rynki zbytu }\end{array}$ & $\begin{array}{l}\text { - zwiększenie wydajności produkcji } \\
\text { - zastosowanie nowoczesnych } \\
\text { technologii } \\
\text { - konkurowanie z zagranicznymi } \\
\text { podmiotami (z Niemiec i Chin) }\end{array}$ \\
\hline Skala makro & $\begin{array}{l}\text { - przesunięcie środków kapitałowych } \\
\text { z tradycyjnych sektorów } \\
\text { - zmniejszenie liczby zatrudnionych } \\
\text { w tradycyjnych sektorach }\end{array}$ & $\begin{array}{l}\text { - zwiększenie poziomu wykorzystania } \\
\text { potencjału naukowego } \\
\text { - mobilizowanie innowacyjności w skali } \\
\text { całej gospodarki } \\
\text { - rozwój sektorów powiązanych } \\
\text { - wzrost zatrudnienia w nowych } \\
\text { sektorach }\end{array}$ \\
\hline
\end{tabular}

Źródło: opracowanie własne

\section{Działania na RZecz ZaZIELENIENia PRZEMysŁu w Polsce}

W polskich warunkach realizacja projektów związanych z zazielenieniem przemysłu natrafia na trudności związane z dotychczasowymi praktykami produkcyjnymi i konsumpcyjnymi. Ich zmiana wymaga przedsięwzięć, które przyczynią się do modyfikacji jakościowej omawianych procesów, ale równocześnie pozwolą na utrzymanie konkurencyjności. Kluczowe są tutaj dwie kwestie. Pierwsza dotyczy wykorzystania istniejących technologii przyjaznych dla środowiska naturalnego, a druga zwiększenia roli produkcji i eksportu towarów środowiskowych. W obu przypadkach bariery stanowią przyzwyczajenia, sygnały cenowe promujące rozwiązania mniej korzystne dla środowiska, utrudniony dostęp do źródeł finansowania oraz niska świadomość konsumentów (Szanse i zagrożenia ..., 2009: 8-9). 
Dlatego też kwestia zmiany tych czynników wiąże się z wprowadzeniem przekształceń mających charakter restrukturyzacyjny w skali makro oraz mikro.

Biorąc pod uwagę powyższe, należy wskazać na postęp w zakresie rozwoju odnawialnych źródeł energii (OZE), energooszczędności oraz emisyjności. Postęp w pierwszym zakresie jest najmocniejszą stroną krajowych przekształceń. W 2008 roku udział OZE w krajowym zużyciu energii elektrycznej brutto wynosił 4,3\%, a w 2012 już 10,6\% (Energia ze źródet odnawialnych..., 2013: 60) (tab. 10).

Tab. 10. Produkcja energii ze źródeł odnawialnych w GWH w 2012 roku

\begin{tabular}{|c|c|c|c|c|c|}
\hline Wyszczególnienie & 2008 & 2009 & 2010 & 2011 & 2012 \\
\hline OZE w GWH & 6606,0 & 8678,7 & 10888,8 & 13137,0 & 16878,9 \\
\hline
\end{tabular}

Źródło: Energia ze źródeł odnawialnych..., 2013: 57

Niestety, równocześnie nie zmienia się na korzyść poziom energochłonności polskiej gospodarki, szczególnie przemysłu (tab. 11).

Tab. 11. Energochłonność polskiego przemysłu (kgoe/euro05)

\begin{tabular}{|l|c|c|c|c|}
\hline \multicolumn{1}{|c|}{ Przemys1 } & 2008 & 2009 & 2011 & 2012 \\
\hline spożywczy & 0,237 & 0,188 & 0,195 & 0,204 \\
\hline tekstylny & 0,076 & 0,064 & 0,051 & 0,049 \\
\hline drzewny & 0,337 & 0,345 & 0,392 & 0,394 \\
\hline papierniczy & 0,295 & 0,508 & 0,460 & 0,437 \\
\hline chemiczny & 1,058 & 1,103 & 1,131 & 1,118 \\
\hline mineralny & 0,770 & 0,747 & 0,654 & 0,605 \\
\hline hutniczy & 1,866 & 1,145 & 1,197 & 1,197 \\
\hline maszynowy & 0,037 & 0,035 & 0,029 & 0,027 \\
\hline środków transportu & 0,074 & 0,056 & 0,042 & 0,044 \\
\hline pozostały & 0,072 & 0,071 & 0,079 & 0,074 \\
\hline
\end{tabular}

Źródło: Efektywność wykorzystania energii..., 2013: 56-57

Ponadto na wysokim poziomie utrzymuje się zużycie energii elektrycznej (tab. 12). W 2012 roku było to $145857 \mathrm{GWh}$, co stanowi zmianę w stosunku do 2010 roku o 3\% (Zużycie paliw..., 2011: 10).

Druga kwestia dotyczy udziału towarów i usług przyjaznych dla środowiska naturalnego w eksporcie światowym. Wkład Polski szacuje się na poziomie 0,9\%, podczas gdy Niemiec - 4,2\%, a Wielkiej Brytanii - 3,7\% w latach 2011-2012 (Low carbon environmental..., 2012). 
Tab. 12. Zużycie energii elektrycznej GWh w 2012 roku w Polsce i w poszczególnych województwach

\begin{tabular}{|l|r|r|c|c|}
\hline & $\begin{array}{c}\text { Zużycie } \\
\text { ogółem }\end{array}$ & $\begin{array}{c}\text { Górnictwo } \\
\text { i kopalnictwo }\end{array}$ & $\begin{array}{c}\text { Przemysł } \\
\text { i budownictwo }\end{array}$ & $\begin{array}{c}\text { Dostawa wody; } \\
\text { gospodarowanie } \\
\text { odpadami }\end{array}$ \\
\hline Polska & 145857 & 8622 & 45806 & 2577 \\
\hline dolnośląskie & 12916 & 2049 & 3074 & 329 \\
\hline kujawsko-pomorskie & 7529 & 32 & 3535 & 127 \\
\hline lubelskie & 5528 & 256 & 2304 & 70 \\
\hline lubuskie & 3278 & 49 & 1319 & 62 \\
\hline łódzkie & 11008 & 1090 & 1811 & 141 \\
\hline małopolskie & 12497 & 341 & 4177 & 200 \\
\hline mazowieckie & 22177 & 18 & 7353 & 361 \\
\hline opolskie & 4845 & 32 & 1896 & 55 \\
\hline podkarpackie & 4979 & 53 & 1699 & 78 \\
\hline podlaskie & 2787 & 30 & 796 & 67 \\
\hline pomorskie & 7620 & 16 & 2925 & 144 \\
\hline śląskie & 25505 & 3981 & 7374 & 484 \\
\hline świętokrzyskie & 4800 & 89 & 1972 & 49 \\
\hline warmińsko-mazurskie & 3482 & 14 & 858 & 91 \\
\hline wielkopolskie & 11061 & 581 & 2966 & 174 \\
\hline zachodniopomorskie & 5844 & 11 & 1745 & 145 \\
\hline
\end{tabular}

Źródło: Zużycie paliw i nośników energii w 2012 r. (2013), Warszawa: GUS, 14

Inwestycje związane z wdrażaniem rozwiązań przyjaznych dla środowiska naturalnego są kosztowne. Dlatego też nie są one zbyt powszechne. Należy jednak podkreślić, że istnieje wiele przyczyn, dla których są one podejmowane:

- konieczność przestrzegania regulacji prawnych z zakresu ochrony środowiska naturalnego,

- europejski system handlu uprawnieniami do emisji gazów cieplarnianych (Emission Trading Scheme, ETS),

- nowoczesne technologie,

- innowacyjność,

- oszczędności energii i surowców,

- konkurencja ze strony zagranicznych przedsiębiorstw,

- nacisk społeczny.

Jednocześnie należy wskazać na cel strategii Europa 2020, jakim jest rozwijanie bardziej konkurencyjnej, zielonej i wydajnej pod względem wykorzystania surowców gospodarki (Europe 2020, 2010). Zakłada ona realizację działań w kilku obszarach priorytetowych, w tym w odniesieniu do przemysłu:

- Europa efektywnie korzystająca z zasobów, 
- polityka przemysłowa w erze globalizacji.

Szczególnie w odniesieniu do tej ostatniej Komisja Europejska kładzie nacisk m.in. na analizę konkurencyjności gałęzi przemysłu oraz zwiększenie wydajności wykorzystania surowców w obszarze nowoczesnych technologii.

Polski rząd rozpoczął działania w tym kierunku poprzez programy, regulacje prawne oraz mechanizmy finansowania projektów inwestycyjnych (tab. 13.)

Tab. 13. Przykłady rozwiązań zachęcających do proekologicznych praktyk inwestycyjnych

\begin{tabular}{|c|c|c|c|c|c|}
\hline Regulacje & Instrumenty & Program & $\begin{array}{l}\text { Akcelerator } \\
\text { ekoinnowacji }\end{array}$ & $\begin{array}{c}\text { System } \\
\text { finansowania }\end{array}$ & Podmioty \\
\hline $\begin{array}{l}\text { Ustawa } \\
\text { o efektywności } \\
\text { energetycznej } \\
\text { z dnia } 15 \text { kwiet- } \\
\text { nia } 2011 \text { r. } \\
\text { (Dz.U. nr 94, } \\
\text { poz. } 551 \text { z późn. } \\
\text { zm.) }\end{array}$ & $\begin{array}{l}\text { Tzw. białe } \\
\text { certyfikaty, } \\
\text { zielone } \\
\text { zamówienia } \\
\text { publiczne }\end{array}$ & $\begin{array}{l}\text { Narodowy } \\
\text { Program } \\
\text { Rozwoju } \\
\text { Gospodarki } \\
\text { Niskoemisyjnej, } \\
\text { Krajowy plan } \\
\text { działań dotyczą- } \\
\text { cy efektywności } \\
\text { energetycznej } \\
\text { (EEAP) } 2007\end{array}$ & Green Evo & \begin{tabular}{|l|} 
Polskie \\
Inwestycje \\
Rozwojowe, \\
dofinan- \\
sowanie \\
z Narodowego \\
Funduszu \\
Ochrony \\
Środowiska \\
i Gospodarki \\
Wodnej \\
(NFOŚiGW)
\end{tabular} & $\begin{array}{l}\text { Stowarzyszenie } \\
\text { Polski Ruch } \\
\text { Czystszej } \\
\text { Produkcji }\end{array}$ \\
\hline
\end{tabular}

Źródło: opracowanie własne

Zarówno ustawa o efektywności energetycznej, jak i białe certyfikaty dotyczą przedsiębiorstw sprzedających energię elektryczną, ciepło lub paliwa gazowe odbiorcom końcowym. Pozostałe przykłady rozwiązań dotyczą firm zainteresowanych wdrażaniem rozwiązań przyjaznych dla środowiska naturalnego - energooszczędnych i innowacyjnych przedsięwzięć związanych z ekowydajnością czy eksportem ekologicznych dóbr i usług.

\section{WNIOSKI}

Trzecia rewolucja przemysłowa jest związana z wdrażaniem rozwiązań przyjaznych dla środowiska naturalnego, takich jak: zwiększenie wydajności w zakresie wykorzystania surowców i energii w procesach produkcyjnych, zmniejszenie emisji gazów cieplarnianych, a także poszerzanie oferty asortymentowej wytwarzanych dóbr o produkty ekologiczne. Tego rodzaju działania wymagają przeprowadzenia gruntownych zmian - przez państwo w sferze polityki gospodarczej w ujęciu szerokim i wąskim, w polityce sektorowej oraz w praktyce poszczególnych przedsiębiorstw. Z uwagi na jakościowo nowy wymiar niezbędnych przekształceń strukturalnych możemy mówić o procesie restrukturyzacji. Przy czym ze względu na obowiązkowy radykalizm w tej materii podejmowane obecnie działania należy uznać za realizację programów związanych z zazielenieniem gospodarek. Określenie restrukturyzacji zostało tutaj celowo użyte w związku z ponownym zainteresowaniem sektorem, a dokładniej 
z uwagi na jego potencjał w zakresie kształtowania PKB, a także oddziaływania na środowisko naturalne. Powiązanie tych dwóch kwestii poprzez podnoszenie wydajności procesów produkcyjnych jest przedmiotem inicjatyw inwestycyjnych podejmowanych przez państwa w programach antykryzysowych.

Przemysł podlega tym zmianom. Jednak jest to, w warunkach polskich, wynik konieczności sprostania wymogom prawnym, dotyczącym oddziaływania na środowisko naturalne emisji gazów cieplarnianych czy efektywności energetycznej. Świadczą o tym m.in. dane dotyczące nakładów na środki trwałe, służące ochronie środowiska i dominującej roli inwestycji „końca rury”, a także niewielki udział w eksporcie dóbr przyjaznych dla środowiska naturalnego. Inaczej rzecz się ma w odniesieniu do małych i średnich przedsiębiorstw, dla których możliwości oszczędzania energii i surowców stanowią priorytet.

\section{Literatura \\ References}

Edwards, C. (2010). Time to lead by example [reindustrialisation through green technologies]. Engineering and Technology, 5, 12.

Efektywność wykorzystania energii w latach 2002-2012 (2013). Warszawa: GUS.

Energia ze źródet odnawialnych w 2012 roku (2013). Warszawa: GUS.

Europe 2020. A strategy for smart, sustainable and inclusive growth. (2010). Brussels: European Commission.

Fiedor, B., Kociszewski, K. (2010). Ekonomia rozwoju. Wrocław: Wydawnictwo Uniwersytetu Ekonomicznego we Wrocławiu.

Górka, K., Szyja, P. (2012). Znaczenie zrównoważonego i trwałego rozwoju w polityce regionalnej Unii Europejskiej. W: M. Adamska, Ł. Dymka (red.) Kapitał ludzki i społeczny w rozwoju regionalnym. Tom II. Opole: Politechnika Opolska.

Jovane, F., Yoshikawa, H., Alting, L., Boe, C.R., Westkamper, E., Williams, D., Tseng, M., Seliger, G., Paci, A.M. (2008). The incoming global technological and industrial revolution towards competitive sustainable manufacturing. CIRP Annals - Manufacturing Technology, 57.

Kassenberg, A., Śniegocki, A. (2010). Rola (eko)innowacji w niskoemisyjnej transformacji. Projekt „Niskoemisyjna Polska 2050”. Warszawa: Instytut na rzecz Ekorozwoju, Instytut Badań Strukturalnych, European Climate Foundation. Za: Grodzka D., Zygierewicz A. (2008). Innowacyjność polskiej gospodarki. Warszawa: Biuro Analiz Sejmowych.

Kochanowski, J. (2012, 8-14 lutego). Widziane z morza. Polityka, 6 (2845).

Kołodko, G. W. (2010). Neoliberalizm i systemowy kryzys globalnej gospodarki. W: G.W. Kołodko (red.). Globalizacja, kryzys i co dalej? Warszawa: Wydawnictwo Poltext.

Kożuch, M. (2012). Polityka przemysłowa w warunkach kryzysu gospodarczego. W: P.P. Małecki (red.). Ekonomia przemysłowa w warunkach kryzysu finansowego. Kraków: Uniwersytet Ekonomiczny, Fundacja Uniwersytetu Ekonomicznego w Krakowie.

Low carbon environmental foods and services (2013). London: Report of Department for Business Innovation \& Skills.

Nakłady na środki trwałe w gospodarce narodowej w 2012 roku (2013). Warszawa: GUS.

Ochrona środowiska 2013 (2013). Warszawa: GUS, s. 389.

Pojęcia stosowane $w$ badaniach statystycznych statystyki publicznej. (2014, 25 listopada). GUS. Pozyskano z http://old.stat.gov.pl/gus/definicje_PLK_HTML.htm?id=POJ-6849.htm

Proekologiczne zachowania małopolskich przedsiębiorstw. Raport z badania. (2011). Kraków: Małopolskie Obserwatorium Gospodarki. 
Rachwał, T. (2006). Efekty restrukturyzacji wybranych przedsiębiorstw przemysłowych Polski Południowo-Wschodniej. Prace Komisji Geografii Przemystu Polskiego Towarzystwa Geograficznego, 9 .

Rachwał, T., Wiedermann, K., Kilar, W. (2009). Rola przemysłu w gospodarce układów regionalnych Unii Europejskiej. Prace Komisji Geografii Przemystu Polskiego Towarzystwa Geograficznego, 14.

Robins, N., Clover, R., Singh, C. (2009). A Climate for Recovery: The Colour of stimulus goes green. Londyn: HSBC.

Rocznik statystyczny przemystu (2012). Warszawa: GUS.

Signes, A., Segaraa-Oña, M., Alvarez, C. (2014). Why do Services and Manufacturing Firms Envision Environmental Innovation Differently? A Path Model Comparision. Polish Journal of Environmental Studies, 23, 5.

Stefaniak, P. (2014, 21 listopada). Ekspert: dlaczego w Europie jest mniej przemystu? Pozyskano $\mathrm{z}$ http://finanse.wnp.pl/dlaczego-w-europie-jest-mniej-przemyslu,218356_1_0_0.html

Szanse i zagrożenia dla przemystu związane z rozwojem ,zielonej gospodarki”." (2009). Kraków: Instytut Gospodarki Surowcami Mineralnymi i Energią PAN.

Szmytkowska, M., Czepczyński, M. (2004). Przemysł w mieście poprzemysłowym. Przykład Gdyni. Prace Komisji Geografii Przemystu Polskiego Towarzystwa Geograficznego, 7.

Szpak, J. (2007). Historia gospodarcza powszechna. Warszawa: Polskie Wydawnictwo Ekonomiczne.

Szyja, P. (2011). Rola „zielonych” inwestycji w programach antykryzysowych Stanów Zjednoczonych oraz Unii Europejskiej. Ekonomia i Środowisko, 1 (39).

Szyja, P. (2012). Zielone programy rozwoju gospodarczego. W: J. Famielec, K. Wąsowicz (red.). Ekonomiczne, finansowe i ekologiczne bariery wzrostu gospodarczego i rozwoju przedsiębiorstw. Raport z badań statutowych. Kraków: Uniwersytet Ekonomiczny.

Szyja, P. (2013a). Tworzenie „zielonych” miejsc pracy w sytuacji kryzysu gospodarki realnej. W: S. Partycki (red.). Teorie kryzysu. Lublin: Wydawnictwo KUL.

Szyja, P. (2013b). Znaczenie programów Zielonego Nowego Ładu dla rozwoju społeczno-gospodarczego. K. Górka, P. Szyja (red.). Zielony Ład Gospodarczy oraz wybrane problemy rynku energii i gospodarki wodnej. Biblioteka „Ekonomia i Środowisko”, 35, Kraków.

Zużycie paliw i nośników energii w 2010 roku (2011). Warszawa: GUS.

Zużycie paliw i nośników energii w 2012 roku (2013). Warszawa: GUS.

Paulina Szyja, dr, adiunkt w Katerze Ekonomii i Polityki Gospodarczej Instytutu Politologii Uniwersytetu Pedagogicznego w Krakowie. Autorka w pracy naukowej podejmuje zagadnienia zrównoważonego i trwałego rozwoju, zielonej gospodarki, bezpieczeństwa ekologicznego. Interesuje się ponadto kwestiami polityki klimatyczno-energetycznej Unii Europejskiej. Jest członkiem: European Association of Environmental and Resource Economists, Polskiego Stowarzyszenia Ekonomistów Środowiska i Zasobów Naturalnych, Polskiego Towarzystwa Ekonomicznego (oddział w Krakowie), Stowarzyszenia Księgowych w Polsce (oddział w Krakowie).

Paulina Szyja, Ph.D., Pedagogical University of Cracow, Institute of Political Science. Research interests: sustainable development, green economy. Member of the European Association of Environmental and Resource Economists, Polish Association of Economists of the Environment and Natural Resources, Polish Economic Society (branch in Krakow), Accountants Association in Poland (branch in Krakow).

\section{Adres/address:}

Uniwersytet Pedagogiczny w Krakowie

Katedra Ekonomii i Polityki Gospodarczej

ul. Podchorążych 2, 30-084 Kraków, Polska

e-mail: paulinaszyja@wp.pl 